\title{
PRACA SOCJALNA W ZMIENIAJĄCYM SIĘ SPOŁECZEŃSTWIE
}

\section{STARE I NOWE DYLEMATY PRACY SOCJALNEJ}

W wielkiej liczbie definicji pracy socjalnej ${ }^{1}$ najbardziej przekonujące wydają mi się te, które postrzegają ją jako jeden wielki projekt interwencyjny skierowany przeciwko barierom uczestnictwa - w godnym życiu, w polityce, w kulturze, w instytucjach społeczeństwa obywatelskiego, w edukacji, w satysfakcjonującej (więc nieopartej na przesadnie wyśrubowanych „kosztach uzyskania”) konsumpcji, w gwarantującym elementarne poczucie bezpieczeństwa systemie opieki zdrowotnej itd. ${ }^{2}$

Natychmiast rodzi się jednak pytanie, z czego owe bariery uczestnictwa wynikaja. W pewnym uproszczeniu można przyjąć, że praca socjalna odpowiadała (i odpowiada) na to pytanie trojako. Po pierwsze, wskazując na (zawiniona i niezawiniona) biedę. Po drugie, wskazując na określone indywidualne deficyty i ułomności - przynajmniej bowiem od kilku dziesięcioleci zdajemy sobie sprawę, że marginalizująca i wykluczająca jest nie tylko bieda, lecz również np. niepełnosprawność, starość czy brak określonych kompetencji społecznych i technicznych ${ }^{3}$. Po trzecie, uznając, że bariery uczestnictwa są bardzo często także rezultatem źle działających, niesprawnych instytucji publicznych oraz wadliwie urządzonego rynku, którego słabnące państwo nie jest w stanie „upilnować".

Na pierwszy rzut oka wszystko jest więc jasne: praca socjalna powinna zajmować się identyfikowaniem barier uczestnictwa. Brzmi to dobrze i rozsądnie. Kłopot w tym, że ów dobrze i wyraziście brzmiący jednozdaniowy program dla pracy socjalnej można rozumieć dwojako: jako (mniej lub bardziej radykalny) program znoszenia wspomnianych barier bądź jako pro-

1 Por. np. B. Szatur-Jaworska, Teoretyczne podstawy pracy socjalnej, w: T. Pilch, I. Lepalczyk (red.), Pedagogika społeczna, Wydawnictwo Żak, Warszawa 1995. Zob. również: ustawa z 12 marca 2004 r. o pomocy społecznej, Dz. U. 2004, Nr 64, poz. 593 ze zm., oraz Globalna definicja profesji pracy socjalnej (oficjalna strona International Federation of Social Workers: http:// ifsw.org/get-involved/global-definition-of-social-work [dostęp: 23.10.2015]).

2 Zob. J. Domon, Wykluczenie, Oficyna Naukowa, Warszawa 2012, s. 11-26.

${ }^{3}$ Bardzo popularne i wręcz swoiście modne stało się w ostatnich kilku latach np. pojęcie $w y$ kluczenia cyfrowego - por. np. M. Popiołek, Wykluczenie cyfrowe w Polsce, „Nierówności Społeczne a Wzrost Gospodarczy” 2013, z. 32. 
gram niwelowania lub chociaż tagodzenia ich konsekwencji. W pierwszym przypadku prędzej czy później najskuteczniejszym narzędziem pracy socjalnej okażą się zapewne prawo i zmiany prawne, ona sama zaś przemieniać się będzie - siłą rzeczy - w politykę społeczną lub politykę po prostu. W drugim przypadku praca socjalna będzie równoznaczna raczej z praca $w$ terenie. Równocześnie zaś jej przebieg i jej skuteczność będą zależeć od tego, jak dobrze (bądź jak źle) prowadzona jest polityka społeczna.

Oczywiście, domyślam się, że wszyscy specjaliści zajmujący się praca socjalna powiedza, że należy robić i jedno i drugie. Że zatem tak samo ważne są zmiany systemowe korygujące, a nieraz wręcz wywracające do góry nogami zastany porządek instytucjonalny, jak i codzienne działania pracowników socjalnych, nawet jeśli często mają one charakter akcyjny i reaktywny i tym samym upodabniaja się do leczenia objawowego. Problem w tym, że i w jednym i w drugim przypadku praca socjalna była, jest i zapewne długo jeszcze będzie zmuszona dokonywać licznych bolesnych i mocno samoograniczajacych ja wyborów. Mówiąc innymi słowy, praca socjalna była, jest i długo jeszcze będzie skazana na rozstrzyganie dziesiątków niewdzięcznych dylematów: czy (i jak bardzo) zbliżać się do władzy, chcąc podpowiadać jej pożądane zmiany instytucjonalne? W jakim stopniu skupiać się na zmniejszaniu „tradycyjnych”, tzn. ekonomiczno-socjalnych nierówności, w jakim zaś na przeciwdziałaniu takim stosunkowo nowym zjawiskom, jak np. podział cyfrowy? Czy „zlecać” realizację poszczególnych zadan socjalno-opiekuńczych organizacjom pozarządowym, urzeczywistniając tym samym zasadę subsydiarności, czy też na odwrót: dążyć do coraz większego „upaństwawiania pracy socjalnej”? Czy skupiać się na zwalczaniu głębszych i bardziej systemowych przyczyn poszczególnych przejawów nieuczestnictwa czy też na działaniach aktywizujących, z których duża część mieć będzie - gdyż inaczej być nie może - jedynie akcyjny charakter? Czy traktować pracę socjalną jako zbiór projektów (mających swych swój początek i koniec, więc i „porzucajacych” swych nominalnych beneficjantów w chwili zakończenia) czy jako zbiór polityk (przynajmniej potencjalnie bardziej stabilnych, a mniej akcyjnych)?

Rozstrzyganie - w taki bądź inny sposób - podobnych dylematów, chcąc nie chcąc, jest równoznaczne z odsłanianiem własnych poglądów i preferencji dotyczących zakresu socjalno-opiekuńczych zobowiązań państwa oraz hierarchii zadań socjalnych. Chcąc nie chcąc, jest ono też równoznaczne z ustalaniem dla pracy socjalnej jakichś priorytetów, jakiejś agendy „spraw do załatwienia". Ta zaś zawsze będzie w jakiś sposób partykularna i stronnicza. Jest więc o czym dyskutować. Jeśli praca socjalna nie jest w stanie zajmować się wszystkim, czym uważa, że powinna się zajać (i do czego jest zobowiązywana choćby przez klasę polityczna), samonarzucającym się przedmiotem jej namysłu nad samą sobą musi być - właśnie - kwestia sposobów, dróg oraz kosztów jej samoograniczania się, takich, które byłyby (jeszcze) akceptowalne dla społeczeństwa i dla niej samej. 


\section{OD PRZECIWDZIAŁANIA BIEDZIE DO PRZECIWDZIAŁANIA „ODWIĘZIOWIENIU"}

Jest jeszcze jeden, kto wie, czy nie najważniejszy i nie największy dylemat, z którym musi się dziśs zmierzyć praca socjalna. Wszyscy jesteśmy wciąż przyzwyczajeni do tego, że najważniejsze źródła marginalizacji i wykluczenia miały i mają w dalszym ciągu przede wszystkim podłoże ekonomiczne. Niemal automatycznie postrzegamy więc pracę socjalną jako straż pożarna, która ma szybko i sprawnie gasić ogniska biedy. Oczywiście jednak - była już o tym mowa - praca socjalna to dzisiaj znacznie więcej. To również program przeprojektowywania społeczeństwa oznaczający m.in. zmaganie się z najróżniejszymi (rasowymi, etnicznymi, płciowymi, generacyjnymi itd.) uprzedzeniami, to setki projektów, których celem jest aktywizacja społeczeństwa, to wspieranie aspiracji podmiotowościowych rozmaitych grup zagrożonych marginalizacja, to propagowanie wtaczajacych strategii dostosowawczych itd.

$\mathrm{Z}$ jednej więc strony zakres zadań pracy socjalnej jest dzisiaj znacznie szerszy niż samo tylko przeciwdziałanie nierównościom ekonomiczno-socjalnym. Z drugiej - można chyba zaryzykować opinię, że praca socjalna, interesując się nierównościami, w znacznie mniejszym stopniu interesowała się jak dotąd różnicami społecznymi (zwłaszcza różnicami światopoglądowymi i politycznymi). Kłopot w tym, że wiele z tych różnic (razem z rosnącą w błyskawicznym tempie złożonością porządku zbiorowego ${ }^{4}$ ) przyczynia się do dezintegracji społeczeństwa i do jego stopniowego znikania. Być może więc praca socjalna powinna umieścić na liście swoich najważniejszych zadań nie tylko przeciwdziałanie nierównościom społecznym, lecz także przeciwdziałanie tym przejawom różnorodności i złożoności, które uruchamiają procesy „odwięziowienia” i które najzwyczajniej mówiąc, niszczą społeczeństwo?

Chciałbym w tym krótkim artykule spróbować zastanowić się nad tą właśnie kwestią: czy rzeczywiście praca społeczna powinna zacząc interesować się procesami dezintegracji społeczeństwa, u podstaw których tkwią nie tyle zró $\dot{z}$ nicowania, ile różnice? Jeśli tak - co miałoby to oznaczać w praktyce? Jeśli nie - jak uzasadniać dystans do tego pomysłu?

\section{KŁOPOTLIWA RÓŻNORODNOŚĆ}

Samo już wspomnienie o tym, że różnorodność społeczeństwa może stwarzać problemy, ma prawo niedobrze się kojarzyć - z trzymaniem kciuków za jakaśs postacią demokratury, z rozczarowaniem pluralizmem, który notabene coraz częściej traktowany jest niemal jako synonim marnotrawnej kultury

${ }^{4}$ Por. R. Drozdowski, T. Szlendak, Socjologia wobec złożoności współczesnego świata, „Studia Socjologiczne" 2013, nr 4(211), s. 7-17. 
nadmiaru ${ }^{5}$. Problem w tym, że różnice, zarówno te, które uchodzą za najważniejsze (np. różnice religijne, etniczne, światopoglądowe), jak i te, którym - zazwyczaj niesłusznie - przypisuje się mniejsze znaczenie (np. różnice w stylu życia, w sferze taktyk i strategii adaptacyjnych), rzeczywiście bywały i bywają źródłem demolujących tkankę społeczną napięć. Większość z tych napięć nie wykracza (przynajmniej współcześnie) poza wymiar symboliczny. Są jednak i takie, które przeradzają się w otwartą behawioralną konfrontację i trwają w tej postaci przez długie lata. Wystarczy wspomnieć wciąz tlący się (w Irlandii Północnej, a nawet w Holandii) konflikt między katolikami a protestantami lub pogłębiające się, przynajmniej od wyborów parlamentarnych w 2007 r., a już na pewno od katastrofy samolotu prezydenckiego w 2010 r. - pęknięcie społeczeństwa polskiego na dwa ostro zwalczające się „plemiona polityczne”. Rzecz zatem nie w tym, aby udawać, że coraz większa mozaikowość porządku zbiorowego ma same dobre strony, ale w tym, by umieć dostrzec związane z nią niebezpieczeństwa i pułapki oraz by potrafić na nie odpowiednio zareagować.

Jak do tej pory mamy jednak z owym „odpowiednim reagowaniem” spore problemy. Przykładem - na pierwszy rzut oka rozsądny - pomysł, by $\mathrm{w}$ religijnie podzielonych społeczeństwach instytucje odpowiadajace za zaspokajanie podstawowych potrzeb z zakresu pomocy społecznej, kształcenia, kultury, opieki zdrowotnej, sportu, rekreacji itd. były zorganizowane zgodnie z „logiką silosową”. Strategię taką przyjęto swego czasu w Holandii, w której protestancki i katolicki porządek instytucjonalny (obejmujaccy nie tylko np. placówki oświatowe i instytucje kultury, ale również media, szpitale, domy opieki społecznej, kluby sportowe itp.) praktycznie nie stykały się ze sobą. Z jednej strony takie rozwiązanie wydaje się dobre i bezpieczne, z drugiej jednak - nietrudno zauważyć, że „logika silosowa” zakładająca równoległe funkcjonowanie dwóch (a niekiedy więcej niż dwóch) porządków instytucjonalnych, które zajmują się tym samym (edukacja, leczeniem, organizowaniem czasu wolnego itd.), lecz adresują swoje oferty do różnych, zantagonizowanych ze soba, nie chcących z sobą współpracować i często nawet: nie chcaccych się zauważać grup i segmentów społeczeństwa jest na swój sposób kapitulancka. Opiera się bowiem na założeniu, że nie da się bądź nie opłaca się przerzucać między skłóconymi ze sobą społecznościami nie tylko mostów, ale nawet kładek. Górę bierze w niej gorzki realizm: jeśli nie ma możliwości współpracy i współdziałania, jeśli różnice aż tak wyraźnie dominują nad podobieństwami, nie pozostaje nic innego, jak będąc formalnie razem (w granicach jednego państwa, jednego porządku konstytucyjnoprawnego), próbować współistnieć na dystans i w bezpiecznym od siebie oddaleniu.

Jeszcze więcej wątpliwości budzą - z oczywistych względów - rozmaite polityki prostoty, które oparte są na dążeniu do redukcji złożoności świata społecz-

\footnotetext{
${ }^{5}$ Więcej na temat kultury nadmiaru zob. „Kultura Współczesna” 2013, nr 1(76). Przywoływany zeszyt kwartalnika „Kultura Współczesna” - opatrzony podtytułem Kultura nadmiaru $w$ czasach niedomiaru - jest w całości poświęcony najrozmaitszym przejawom „nadprodukcji”, „nadpodaży” i „nadreprezentacji” oraz ich kulturowym, społecznym, politycznym i ekonomicznym konsekwencjom.
} 
nego. W najlepszym razie są one równoznaczne z próbami standaryzowania społeczeństwa za pomocą instrumentów biurokratyczno-administracyjnych. W najgorszym - z bezpośrednią przemocą kierowaną przeciwko zasadzie pluralizmu i przeciwko ładowi policentrycznemu ${ }^{6}$.

\section{NOWE ZADANIA DLA PRACY SOCJALNEJ?}

Mam świadomość, że postulat, by praca socjalna zajmowała się (również) aktywnym przeciwdziałaniem zjawiskom prowadzącym do rwania się więzi społecznych, do kurczenia się wspólnych zasobów symbolicznych społeczeństwa i w konsekwencji do jego postępującej dezintegracji, może się wydać wielu - delikatnie mówiąc - chybiony. Jedni powiedza, że przecież przeciwdziałanie dezintegracji społecznej należy do najważniejszych zadań pracy socjalnej właściwie od zawsze. Inni - odczytawszy ten postulat jako nawoływanie do tego, by praca socjalna zajęła się czymś w rodzaju zakrojonych na szeroka skalę negocjacji i mediacji społecznych - stwierdza, że pracownicy socjalni nie mają ani takich kompetencji, ani takich uprawnień. Jeszcze inni uznaja, że $\mathrm{w}$ ostatecznym rozrachunku chodzi w tym wszystkim o maskowanie i gaszenie konfliktów, których podłożem są różne wartości, różne definicje sytuacji i przede wszystkim różne interesy.

Co do drugiej i trzeciej wątpliwości - nie są one całkiem bezpodstawne. Jednakże potwierdzić je może (lub rozwiać) jedynie przyszłość. Co do wątpliwości pierwszej - istotnie, cały szereg projektów i programów realizowanych przez pracowników socjalnych służyło i służy w końcowym rezultacie podtrzymywaniu spójności oraz integracji społeczeństwa. Tak trzeba postrzegać np. inicjowane i realizowane przez pracowników socjalnych - często zresztą w całkowitym osamotnieniu instytucjonalnym - projekty mające zwalczać uprzedzenia (rasowe, etniczne, klasowe, płciowe, generacyjne). Tak trzeba postrzegać działania pracowników socjalnych zmierzające do aktywizowania marginalizowanych (a niekiedy samomarginalizujących się ${ }^{7}$ jednostek i grup społecznych. Tak wreszcie trzeba rozumieć inicjowane przez pracę socjalną przedsięwzięcia-akcje mające nie dopuścić do takiego wzrostu poziomu nierówności społecznych, który zagrażałby już nie tylko niekontrolowanymi wybuchami społecznego niezadowolenia, lecz i wzajemnym niewidzeniem się, wzajemnym nieprzyjmowaniem się do wiadomości najbardziej zantagonizowanych ze soba segmentów społeczeństwa.

Mimo wszystko będę tu jednak upierał się przy opinii, że mamy dziś do czynienia z całą masa zupełnie nowych tendencji dezintegracyjnych, które wymagają zupełnie nowych środków zaradczych, zupełnie nowej wyobraźni

${ }^{6}$ Por. M. Krajewski, Przeciwzłożoność. Polityki prostoty, „Studia Socjologiczne” 2013, nr 4, s. $37-50$.

${ }^{7}$ Por. R. Drozdowski, Wykluczone (?), wykluczajace (?) idiomy mówienia o wykluczeniu, w: D. Semenowicz, K. Tórz (red.), Granice wykluczenia. Między etyka a estetyka - The Boundaries of Exclusion: Between Aesthetics and Ethics, Fundacja Malta, Poznań 2012, s. 81-84. 
socjotechnicznej i zupełnie nowej polityki społecznej. Niektóre z owych nowych tendencji (np. widoczna gołym okiem proliferacja mowy nienawiści ${ }^{8}$ i zalewająca Internet fala hejtu) wydaje się, że sa - prawdopodobnie nieuchronnym - skutkiem ubocznym niewyobrażalnej jeszcze kilkanaście, a nawet kilka lat temu demokratyzacji dostępu do globalnych platform komunikacji. Inne (np. rosnącą liczbę jednostek chcących budować swoje tożsamości w oparciu o prowokacyjnie wyraziste, więc i potencjalnie konfliktogenne różnice i dystanse ${ }^{9}$ ) można pewnie uznać za efekt rozczarowania społeczeństwem opartym na słabych więziach w znaczeniu, jakie nadał temu terminowi Mark Granovetter ${ }^{10}$. Jeszcze inne (np. wzrost liczby konfliktów afektywnych) tłumaczyć należy chyba tym, że dzisiejszy kapitalizm jest coraz bardziej powiązany z emocjami - zarówno dlatego, że na nich bazuje, jak i dlatego, że nimi handluje ${ }^{11}$. Do rwania się więzi społecznych i do dezintegracji społeczeństwa przyczyniało się w przeszłości (i przyczynia się w dalszym ciagu) również państwo. Jak? Choćby forsując regulacje prawne, które - jak głośna ustawa o „podatku janosikowym" - utrwalają i pogłębiają antagonizmy międzyregionalne. Bądź też tworząc systemowe zachęty raczej do indywidualnych niż zbiorowych strategii dostosowawczych lub godząc się (bardziej ze strachu i w wyniku politycznych kalkulacji niż w imię sprawiedliwości społecznej) na uprzywilejowanie niektórych grup zawodowych.

$$
* * *
$$

Kluczowe teraz pytanie brzmi następująco: jak miałoby wyglądać zaangażowanie pracy socjalnej $\mathrm{w}$ przeciwdziałanie wszystkim tym nowym tendencjom dezintegracyjnym? Co jeszcze (lub co inaczej) mieliby robić - ponad to, co już robia - pracownicy socjalni, aby np. zatrzymać nabierajacy tempa proces przekształcania się różnic politycznych w polityczne nienawiści lub pomóc wyrugować frazy języka pogardy nie tylko z Internetu, ale i ze stadionów, z korytarzy szkolnych, ze studiów telewizyjnych i nawet z sal wykładowych? Jak powinni oni pracować i po jakie sięgać narzędzia, jeśli postawilibyśmy im

${ }^{8} \mathrm{Na}$ temat mowy nienawiści - zob. J. Butler, Walczqce stowa. Mowa nienawiści $i$ polityka performatywu, Wydawnictwo Krytyki Politycznej, Warszawa 2010; zob. również S. Kowalski, M. Tulli, Zamiast procesu. Raport o mowie nienawiści, W.A.B., Warszawa 2003.

9 Pierwszym z brzegu przykładem tej tendencji może być działalność nieoficjalnych stowarzyszeń kibiców piłkarskich, które zarządzają nie tylko „ultrasami” odpowiadającymi za atrakcyjne oprawy meczów, ale także „kibolskimi ustawkami” i nawet wojnami grup przestępczych, których członkowie rekrutują się spośród grona stadionowych znajomych. Od lat „dyżurnym” przykładem dążenia do budowania tożsamości w oparciu o prowokacyjnie zaznaczone różnice, które mogą w każdej chwili zaowocować otwartym konfliktem i które poniekąd służą prowokowaniu konfliktów, są również strategie zaznaczania różnicy, po jakie sięgały i sięgają subkultury młodzieżowe (zob. np. D. Muggleton, Wewnatrz subkultury. Ponowoczesne znaczenie stylu, Wyd. UJ, Kraków 2004; zob. też W. Wrzesień, Krótka historia społecznej subkulturowości, WN PWN, Warszawa 2013).

${ }_{10}$ Zob. M. Granovetter, The strength of weak ties, „American Journal of Sociology” 78, 1973, s. 1360-1380. Zob. tė̇ „Człowiek i Społeczeństwo” 33, 2012 w całości poświęcony słabym więziom i słabym formom uwięziowienia.

11 Por. E. Illouz, Uczucia w dobie kapitalizmu, Oficyna Naukowa, Warszawa 2010. 
zadanie edukowania do większej tolerancji społecznej $i$ kulturowej (przyjąwszy wcześniej - niestety chyba zasadnie - że ani szkoła, ani mass media nie wywiąują się z tego zadania zadowalająco)? Czego nowego (czego w ogóle) moglibyśmy/powinniśmy się domagać od pracowników socjalnych, widząc, że np. takie bądź inne podmioty władzy publicznej mające stać na straży dobra wspólnego realizuja politykę dziel i rządź?

Teraz jednak rozczaruję czytelników: nie umiem odpowiedzieć na te pytania. Oczywiście, coś mi się wydaje. Wydaje mi się zatem, że strategicznie ważnym zadaniem dla pracy socjalnej staje się dzisiaj aktywna pomoc (tak naprawdę nam wszystkim) w szukaniu i znajdowaniu wspólnych mianowników - wspólnych doświadczeń, wspólnych zasobów symbolicznych, wspólnych diagnoz i definicji sytuacji, wspólnego minimum aksjonormatywnego, wspólnych bohaterów zbiorowej wyobraźni. Wydaje mi się, że jednym z głównych celów pracy socjalnej powinno stać się wspieranie wszystkich możliwych przejawów demokracji obywatelskiej, poszerzanie (a niekiedy odzyskiwanie) przestrzeni, w obrębie których jej procedury i narzędzia służą nie tylko zwiększaniu poczucia podmiotowości, lecz także rozwiązywaniu konfliktów. Wydaje mi się wreszcie, że praca socjalna powinna intensywnie promować i pomagać urzeczywistniać ideę społeczeństwa kolaboratoryjnego ${ }^{12}$, w którym doświadczenia i wiedza żadnej zbiorowości nie sa z góry dyskwalifikowane i które jest z założenia otwarte nie tylko na współpracę mimo różnic, ale i na współpracę inspirowaną różnicami. Niewykluczone, że do listy najpilniejszych zadań dla pracy socjalnej należałoby dodać jeszcze jedno. Hartmut Rosa napisał niedawno, że warunkiem „dobrego życia” nie jest już dostarczanie (przez rynek, przez państwo) satysfakcjonującej dla jednostek liczby opcji, zasobów, możliwości oraz towarów, lecz rezonowanie rozumiane jako obdarzenie uwaga, słuchanie i odpowiadanie, monitorowanie i reagowanie ${ }^{13}$. Nawet jeśli Rosa trochę przesadza (niestety, długo jeszcze nie wszystkie segmenty społeczeństwa - nawet w bogatych państwach „starej Unii” - będą mogły powiedzieć o swych warunkach socjalno-bytowych i szansach społecznych, że są satysfakcjonujące), prawda jest, iż bardziej empatyczny i responsywny system jawi się coraz większej liczbie obywateli jako jeden z wymogów legitymizacyjnych. Nasycanie instytucji publicznych społeczną empatią i przyuczanie ich do większej responsywności brzmi właściwie już teraz jak samonarzucająca się powinność pracy socjalnej.

Pełniejsza odpowiedź na pytanie, czy i jak przeformułować najważniejsze zadania pracy socjalnej w społeczeństwie, któremu zagraża już nie tyle poszerzanie się sfery biedy i ubóstwa, ile coraz większe odwięziowienie i które zaczyna postrzegać różnice społeczne jako paliwo dla ostrych konfliktów społeczno-kulturowych - należy oczywiście do samej pracy socjalnej.

${ }^{12}$ Coraz większą popularność i uznanie zyskują rozmaite formy projektowania i planowania społecznego, które oparte są na zasadach demokracji partycypacyjnej i których wspólnym rysem jest dowartościowywanie rozmaitych postaci local knowledge (por. C. Geertz, Wiedza lokalna. Dalsze eseje z zakresu antropologii interpretatywnej, Wyd. UJ, Kraków 2005) i rozmaitych form wiedzy potocznej. Więcej na ten temat-zob. np. M. Frąckowiak, L. Olszewski, M. Rosińska (red.), Kolaboratorium. Zmiana i wspótdziałanie, Fundacja SPOT, Poznań 2011.

${ }^{13}$ Zob. H. Rosa, Nachwort, w: K. Dörre, S. Lessenich, H. Rosa, Soziologie - Kapitalismus Kritik. Eine Debatte, Suhrkamp Verlag, Frankfurt am Main 2009. 


\section{ZAMIAST ZAKOŃCZENIA}

Jeśli miałem tu rację, twierdząc, że nowe i najnowsze tendencje dezintegracyjne to nie tylko rezultat np. nowych, atomizujacych technologii, nowych mód lifestylowych czy nowych form uspołecznienia, którym tradycyjnie rozumiane społeczeństwo nie jest już właściwie do niczego potrzebne, ale również rezultat źle działającego państwa - to wymyślająca się na nowo praca socjalna, chcąc nie chcąc, zmuszona będzie zajać bardzo podobne pozycje do tych, jakie zajmuje dziśs socjologia krytyczna. Pytanie, czy rzeczywiście tak będzie. I co się stanie z pracą socjalną wchodzącą w rolę krytyka systemu instytucjonalnego, którego sama jest częścią?

prof. dr hab. Rafat Drozdowski

Uniwersytet im. Adama Mickiewicza w Poznaniu

rafdrozd@amu.edu.pl

\section{SOCIAL WORK IN A CHANGING SOCIETY}

\section{Sum mary}

This article is an attempt to examine the new tasks and functions of social work in a society in which the biggest challenge is no longer the fight with exclusion arising from poverty, but the fight against exclusion originating in social, cultural and political differences. It is also an attempt to look at these tasks and functions in a society increasingly dominated by individuals who are less willing to undertake actions for the common good, who create a 'society of individuals' in which social bonds are loosening. 